\title{
Research Progress on the Resistance of Roof Greening Plant
}

\author{
Shuang Liu+*, Chang-Chun Yuan + ,Ting Xuan and Zi-Ya Chen
}

Life Science and Technology School, Lingnan Normal University, Zhanjiang, 524048, China

liushuangaaa@163.com,yuanchangchun@163.com,982088575@qq.com,

527722629@qq.com

${ }^{+}$The author contributed equally to this work

*For correspondence: liushuangaaa@163.com

Keywords: research progress, resistance, roof greening plant

\begin{abstract}
Roof greening has a series of advantages to improve the urban ecological environment. The roof greening plants resistance to the environment research is one of the scholars research priorities. In the text, the research progress in the studies of roof greening plant resistance are analyzed. Found that a lots of research on the resistant of plants were studied , but the influence on the soil fertility of roof greening plant growth in related research is less reported, therefore, the research direction for future research hotspot, also can be used as roof greening plant growth factors associated with effective supplement.
\end{abstract}

\section{Introduction}

Roof greening is build garden and planting trees flowers on the roof, balcony or large artificial rockery of all kinds of buildings, structures, bridges, etc.[1]. It can be traced back as far as the gardens of Babylon and the Roman Empire, i.e. they grew trees on top of buildings[2]. Roof greening has a series of advantages to improve the urban ecological environment [3-7]. it has become today's urban greening projects a big trend The ecological environment of roof is great difference to the ground, no matter as light, temperature, humidity, soil, etc have obvious difference[8]. So applied to the roof greening plants resistance to the environment research have also become one of the scholars research priorities. In the text, the research progress in the studies of roof greening plant resistance are analyzed, so as to provide beneficial reference for roof greening plant selection.

\section{Research Progress on the Resistance of Roof Greening Plant in Europe}

The probe into plant which suitable for roof greening in Europe is always walked in the world's leading edge. As early as the 19th century, with the discuss on "building large areas of vegetation" in Germany, the plants selection and other roof greening technology were studied[9]. In 1970, Sedum lineare and S.sarmentosum etc were used in roof greening in Germany and Application and popularization in the whole world[9]. Fischer P. tested Sedum album cv. Coral Carpet, Ajuga reptans cv. Atropurpurea, Delosperma othonna and Penstemon pinifolius found that Sedum album cv. Coral Carpet and Ajuga reptans cv. Atropurpurea have good covering ability, strong ability of drought resistance and barren resistance[10].

Kutkova ,T experimented ability of on Herbaceous plants drought resistance and barren resistance in Czech[11].

Oztan ,Y. Arslan. screened 27 species of plants by test the drought resistance of kinds of succulents, include part of the species and varieties of Sedum, Silene gallica Linn., Euphorbia L., and Sempervivum. in Turkey[12].

On thin soil layer thickness case roof plant drought resistance, cold resistance and ground cover ability were studied and selected 11 species of Sedums and several kinds of Sempervivum by Gomez et al. in Spain[13]. To fit for the drought tolerance of roof garden grass seed were studied and 
determine Poa Linn., Sedum leucocarpum and Bryophyte by Panayiotis Nektarios et al. [14].

In Britain, Panayiotis Nektarios et al. measured the effects on growth of Lantana camara L. in four kinds of roof afforestation matrix. Found that Growth after seven months Lantana camara L.has best growth in matrix which sandy loam soil amended with peat and perlite in a proportion of 50-30-20[15]. Dunnett, N. and Nolan, A. screened can adapt to Sheffield area half intensive green roofs of perennial drought-resistant plant[16]. The drought resistance of Sedums were studied by Vanwoert Nicholaus D. et al. The results show that water must be at least once every 14 days pouring with $2 \mathrm{~cm}$ matrix thickness and at least once every 28 days pouring with $6 \mathrm{~cm}$ matrix thicknes. Even if 88 days not water, plants can still grow, show that Sedums able to endure extreme drought conditions, is the preferred thin layer roof greening plants[17].

\section{Research Progress on the Resistance of Roof Greening Plant in America}

The roof greening of America is also developing rapidly in the late $20^{\text {th }}$ century after reference to Europe. Monterusso Michael A. et al. observed 18 kinds of Michigan native plants and 9 kinds of sedum wintering in growth, and by measuring chlorophyll fluorescence to determine plant physiological stress through three years on the roof of a simulation device. The result show that sedum can be normal growth. Allium cernuum L.,Coreopsis lanceolataL.,Opuntia humifosa Raf.,Tradescantia ohiensis L. can adapt to Michigan not watering the open type of roof greening[18].

\section{Research Progress on the Resistance of Roof Greening Plant in Asian}

Japan is one of the countries to develop simple roof greening plants earlier in Asian, there are nearly 40 kinds of sedums and meaty plant used in roof greening[19], a dozen of them already have mature green planting pattern. In 2006 a study found that in addition to sedums plants thyme and Verbena officinalis L. also suitable for Kobe roof greening application in Japanese[20].

\section{Research Progress on the Resistance of Roof Greening Plant in China}

In recent years, in the study of roof greening plant resistance. Sedum lineare and S.sarmentosum showed a greater resistance and good ornamental effect after used on roof greening in Shanghai , which promoted and has achieved good effect[21,22]. Drought, high temperature, low temperature stress experiment of Sedum lineare , S.sarmentosum, Sedum emarginatum, Sedum reflexum cv. and Gynrasegetum was carried out by Huang Wei-chang et al. in Shanghai botanical garden and screened Sedum lineare, Sedum emarginatum and S.sarmentosum for roof greening in Shanghai[23]. Zhang Jie et al. study on the drought resistance of S. sexangulare L, S. spurium Coccineum, S. polytrichoides Hemsl , S.acre L. and S. kamtschaticum Fisch by measuring blade hold water, relative water content, cytoplasmic membrane permeability, CAT and POD activity[24].

Zhao Ding-guo et al. tested the tracking condition of Sedum lineare in winter in Beijing from November 2001 to February 2004, The results show that Sedum lineare completely suitable for roof greening in Beijing[25].The substrate and plant material of the simple type of roof greening were selected after field trials on ultra-low power consumption in Tsinghua university demonstration building roof by Yin Li-feng et al., evaluated the growth of Sedums, perennial flowers and small shrubs in different medium, and green planting patterns were established[26].Wei Yan selected native plants and have successfully domesticated plants, etc satisfies the requirement of roof greening in Beijing special environment, for example Thyme, radix rehmanniae and so on dozens of non Sedum plants and Sedum morganianum, Sedum spurium cv.Coccineum and so on Sedum plants. And studied On the drought resistance, resistance to high temperature and high humidity, such as cold adaptability[56]. 


\section{Conclusion}

At present, represented by Germany international roof greening is most simple type of roof greening, this way of low cost, quick effect, late can be extensive management, suitable for large-scale popularization and application. For simple roof greening, low, shallow root system, heat-resistant, hardy and early resistance, wind resistance, salt resistance, disease resistance characteristics of perennial plant is preferred[27]. Scholars also for a variety of perennial plants resistant to do a lot of research, but the influence on the soil fertility of roof greening plant growth in related research is less reported, therefore, the research direction for future research hotspot, also can be used as roof greening plant growth factors associated with effective supplement.

\section{Acknowledgements}

This research is supported by National Spark Program of China (2013GA780074); Collaborative Innovation Center Project of Lingnan Normal University (CIL1503) and Guangdong Natural Science Foundation (2016A030307016)

\section{References:}

[1] Oberndorfer E, Lundholml J,Bass B, et al. Green roofs as urban ecosystems: ecological structures, functions, and services. Bioscience.2007(10)823-833

[2]Peck, S.W., 2002. Green Roofs: Infrastructure for the 21st Century. $1^{\text {st }}$ Annual Urban Heat Island Summit 2002, Toronto.

[3] Fioretti R. etc. Green roof energy and water related performance in the Mediterranean climate. Build. Environ. 2010(45)1890-1904

[4] Mackey C.W. etc. Remotely sensing the cooling effects of city scale efforts to reduce urban heat island. Built Environ. 2012(49)348-358

[5] $\mathrm{Li} \mathrm{J}$. etc. Effect of green roof on ambient $\mathrm{CO}_{2}$ concentration. Build Environ. 2010(45)2644-2651

[6] Jim, C.Y., Tsang, S.W. Biophysical properties and thermal performance of an intensive green roof. Build Environ. 2011(46)1263-1274

[7] Oberndorfer E. etc. Green roofs as urban ecosystems: ecological structures, functions, and services. Bioscience 2007(57)823-833

[8] Fischer P. Greening of outdoor surfaces on a thin layer of expanded clay. DeutscherGartenbau.1987.(41)

[9] Rong an. Large Area Vegetarieren of Building Environment in German Cities. World Architecture. 2002(12).59-60

[10] Yin Li-feng, Li Shu-hua. Roof Garden Technology in Japan. Chinese landscape architecture. 2005(5):62-66

[11] Kutkova ,T. Herbaceous plants for sites with extreme conditions in landscape architecture. [Czech] .Acta Universitatis Agriculturae. 1990(5)

[12] Oztan ,Y. Arslan. Research carried out to determine the species of succulent plants that can be grown in the ecological conditions of Central Anatolia region and the possibilities of their use as ground cover from the landscape architectural point of view. [Turkish]. Doga.Turk Tarim ve Ormancilik Dergisi. 1993(17)

[13] Gomez etc. Plant species in green roof.[Spanish]. Agricultura Revista Agropecuaria 1996 
[14] Panayiotis Nektarios et al. Comparison of different roof garden substrates and their impact on plant growth. Acta Hort. 2004(643)311-313

[15] Panayiotis Nektarios et al. Soil amendments reduce roof garden weight and influence the growth rate of Lantana. HortScience.2003(38)618-622

[16] Dunnett, N. and Nolan, A. The effect of substrate depth and supplementary watering on the growth ofnine herbaceous perennials in a Semi-extensive green roofs. Acta Hort. 2004(643)305-309

[17] Vanwoert Nicholaus D. et al. Watering regime and green roof substrate design affect Sedum plant growth. HortScience.2005(40)659-664

[18] Monterusso Michael A. et al. Establishment and persistence of Sedum spp. and native taxa for green roof applications.HortScience.2005(40)391-396

[19] Tokyo roof greening bureau. Tajima roofing. http:// www. tajima-roof.co.jp.2003.11

[20] Sendo et al. Faculty of Agriculture[A]. Abustracts $27^{\text {th }}$ International Horticultural Congress and Exhibitotion.2006:433.www.ihc2006.org

[21] Ni Tong-liang. Of choice for building roof greening plants S.sarmentosum. Greening and Life.1997(4)9-10

[22] Zhao Ding-guo et al. A Good Plant Suitable For Roof Greening Preliminary Investigation Sedumlineare. Acta Agriculturae Shanghai.2001(4)58-59

[23] Huang Wei-chang et al. Study On The Application of Sedums on Roof Garden in Shanghai. Journal of Anhui Agricultural Sciences.2005(33)1041-1043

[24] Zhang Jie et al. Study on drought resistance of sedums in light roof greening. Northern Horticulture.2007(1)122-124

[25] Zhao Ding-guo et al. The beginning of the experiment on Sedum lineare in Beijing early winter . Grassland and Turf.2005(1)71-72

[26] Yin Li-feng, Li Shu-hua. The Selection of Growing Media and the Establishment of Planting

Mode for Roof Greening. Landscape Architecture.2006(4)46-49

[27] Emily Hauth, Tom Liptan. Plant survival finding in the Pacific Northwest Chicago conference.2003(05) 